\title{
Preparedness to Implement a Spatial Plan: The Impact of the Land Cooperative in Central Bangka Regency
}

\author{
Ragil Haryanto ${ }^{1, *}$, Imam Buchori ${ }^{1}$, Nany Yuliastuti ${ }^{1}$, Ibnu Saleh ${ }^{2}$, Agung Sugiri ${ }^{1}{ }^{\circledR}$, \\ Bagus Nuari ${ }^{3}$ and Nisriena Rachmi Putri ${ }^{3}$ \\ 1 Department of Urban and Regional Planning, Faculty of Engineering, Diponegoro University, \\ Semarang 50275, Indonesia; imambuchori@lecturer.undip.ac.id (I.B.); n.yuliastuti@pwk.undip.ac.id (N.Y.); \\ agung.sugiri@uqconnect.edu.au (A.S.) \\ 2 Central Bangka Regency Government, Koba 33681, Indonesia; pu@bangkatengahkab.go.id \\ 3 Urban Development Laboratory, Department of Urban and Regional Planning, Faculty of Engineering, \\ Diponegoro University, Semarang 50275, Indonesia; bagusnuari@gmail.com (B.N.); \\ nisrina.2008@yahoo.com (N.R.P.) \\ * Correspondence: ragil.haryanto@pwk.undip.ac.id
}

Received: 28 October 2020; Accepted: 16 December 2020; Published: 21 December 2020

\begin{abstract}
Cities are currently struggling with increasingly limited land availability and rising land prices in urban areas. In this regard, proper land management can control land prices and optimize space to be effective, efficient and sustainable. This paper presents the results of research in Sungai Selan, a small city of Central Bangka Regency. It focuses on the forms of land management by determining the community and stakeholder readiness in a Land Cooperative Institution to implement a Detail Urban Spatial Plan (RDTRK), especially concerning land consolidation. We conducted this study during the Covid-19 pandemic and, therefore, research methods were adapted to suit the prevailing conditions by uploading expert priority choices online. The experts involved were those considered the main stakeholders of RDTRK implementation, such as representatives from the local government agencies, members of the Local Council of People Representative (DPRD), and selected members of cooperatives dealing with land and spatial issues. The results show that stakeholders are in general ready to establish land cooperatives and incorporate into RDTRK implementation with certain conditions.
\end{abstract}

Keywords: implementation; land consolidation; land cooperative; spatial planning; urban development; urban management

\section{Introduction}

The provision of land for development needs, especially in urban areas, is a complex problem. In many cases, urban growth, which is usually characterized by agglomeration and the growth of industries, is followed by fluctuations in land prices leading to massive land reduction for other purposes mostly public use [1].

The increasing land demand may have implications for prices, which mainly depend on the location [2]. According to empirical studies, economic growth plays a vital role in the expansion of urban land and the development of land markets [3]. Apart from individual characteristics of land parcels, including structural and location attributes, urban land prices are closely related to the environmental effects of the region's socioeconomic, political, and geographical characteristics [4-6]. A US-based study has used data from the 94 largest standard metropolitan statistical regions reported in the 1980 census [7]. It has confirmed that the socioeconomic and geographical characteristics of cities, including average real household income, climate, crime rates, population growth, population density, and construction costs, have influenced inter-city land prices. 
The land cooperative concept, as part of land management, can help to overcome the problem of land needs for development. Initially, it was there in land management applied to the agricultural sector. The concept, along with land banking, has been progressing since then, especially in the study area of Urban and Regional Planning. The USA is among the pioneers applying the land bank concept. Other countries that also apply land banking include the Netherlands, Switzerland, Sweden, Singapore and Thailand. The main difference between land cooperative and land bank lies in the term of cooperative, which is an antonym of competitive, applicable for the land bank.

Some countries implement land consolidation for urban development needs, such as in Ethiopia [8]. Germany and the Soviet Union also carried out the land consolidation pattern in the past [9]. The compilation of City Detailed Spatial Planning Documents, followed by Land Management, is expected to control land price increases. This controlling function is achievable by making land management effective and preventing suboptimal use of land. In general, to implement an urban spatial plan effectively, land consolidation can be used to distribute land ownership appropriately, providing the infrastructure needed to meet urban development. The application of urban land consolidation has been there in many countries, including Australia, Germany, Japan, the Netherlands, Sweden, Indonesia, Taiwan, and Thailand [10,11].

Distribution of land requires a small fee that can be through the mechanism of land banks. According to Alexander [12], land banking is among the strategies to help the conversion of abandoned and delineated properties into productive use. Land banking can bridge the government, private sector and the community in the implementation of spatial plans. However, land banks in Indonesia have not yet materialized, especially in the urban and regional levels.

An appropriate implementation of the spatial plan requires community participation. With land cooperatives, the scheme can be successful [13]. This is because all stakeholders, including the community, can involve appropriately in decision making. The government may implement the spatial plan as the community's contribution to land value since land availability is an essential element in development. The most common challenge is encountered in the financing and acquisition of suitable land for development by the government. It often results in a prolonged procurement process.

The implementation process takes several approaches, including land consolidation, where the scheme could make a particular party worse off [10]. Therefore, there would most probably be a need for mediation institution such as land cooperative to keep a fair play among the parties [14]. The cooperative can act as a bottom-up agent based on the capital of the community members who own land, and the benefits are distributed to them equitably. At the local level of developing countries like Indonesia, land cooperative is a new concept helping the national, regional and local governments in the implementation of their plans, especially the detail urban spatial plans (RDTRK).

Therefore, this study has aimed to assess the stakeholders' readiness for the establishment of land cooperatives to help improve the preparedness to implement RDTRK. We have completed the research in 2020, during which the Covid-19 pandemic has made researchers unable to apply the best methods. The case of this study is Sungai Selan urban area of Central Bangka Regency (see Figure 1), which RDTRK has already been ready to implement. 


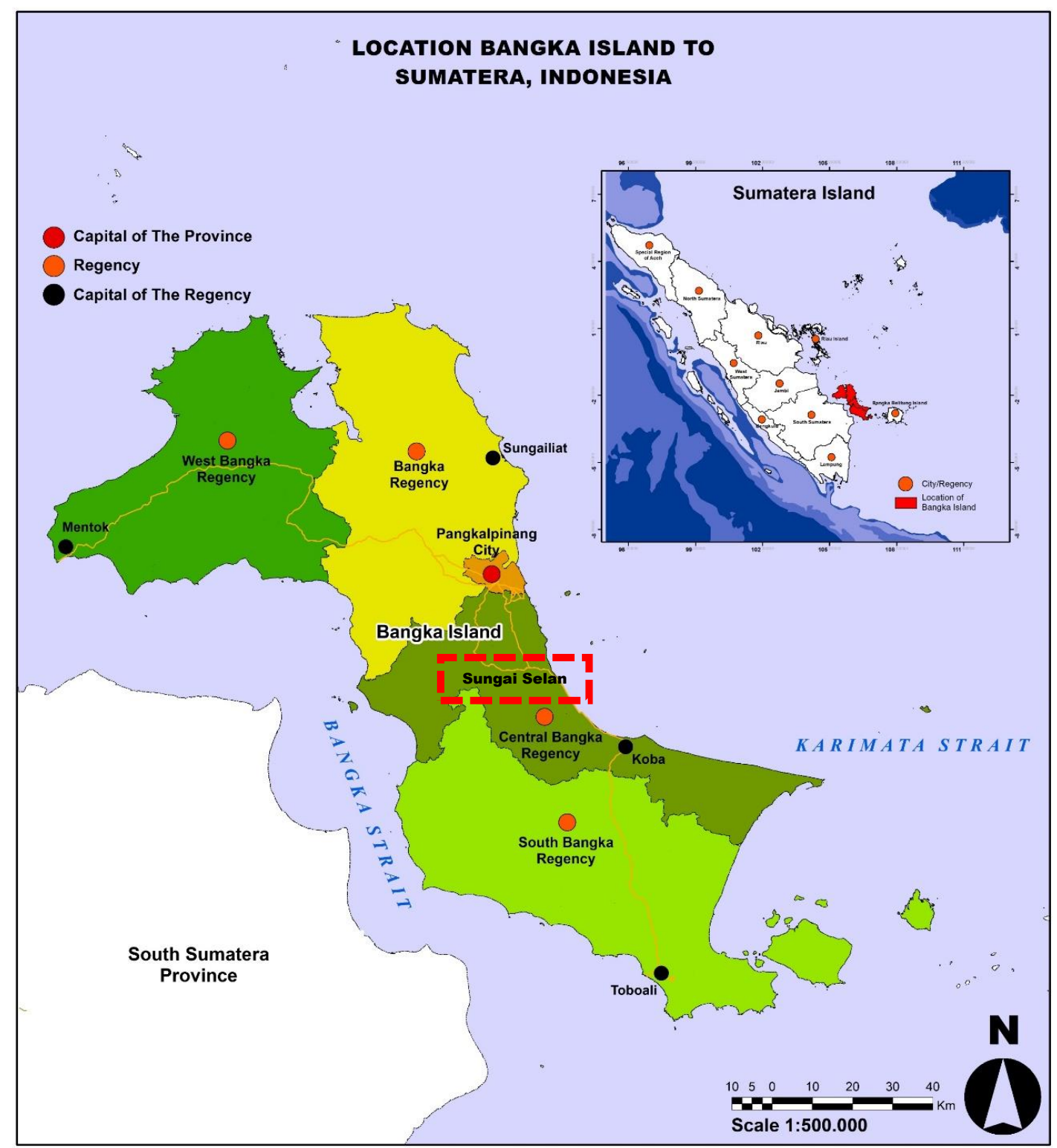

Figure 1. Sungai Selan in Central Bangka Regency as the case study (own drafting on the scale of 1 to 500,000 referring to https://www.sejarah-negara.com/2017/04/peta-bangka-belitung).

\section{Can Land Cooperatives Help in Urban Spatial Plan Implementation?}

In urban land management for the implementation of a spatial plan, the availability of land owned by the public has a positive impact for at least three reasons. First, it is critical to promote appropriate and efficient land-use patterns and controlled growth. Private ownership would at least bring a problem of conversion in implementing a land-use plan, especially for the designated public use. Second, it provides social justice and ensures that the community can share the benefits of land development. Third, it can help facilitate the government in providing infrastructure and public facilities. Pieces of evidence have shown the followings [15]:

1. Bureaucracy may make decisions that would be misleading to nonprogressive, insensitive, and inefficient land use.

2. Monopoly ownership of the planned public land-use might lead to exploitation by the private sector. 
3. Public land ownership would not necessarily reduce the increase in land value. Land can be dynamic under any circumstances, including mixed economic conditions such as balanced public and private sectors.

To ensure land availability for various public uses, developing institutions like land cooperatives may help. Land cooperatives refer to a form of land management based on decentralization, which is effective and sustainable at the local level [16]. Initially, it was the agricultural development that applied the cooperative concept. For this reason, many pieces of literature provide information on land cooperatives and consolidation in the agricultural context. Generally, land cooperatives are critical in developing more sustainable food systems. It is a democratic model that shows many features of general principles for good governance through the mandated structure, implementation and use of organic agriculture [17]. In China, the cooperative economy developed a deep foundation after 1970, which collaboratively managed agricultural and industrial production functions. Learned from the agriculture sector, in Nanhai, China, the cooperative concept was introduced into land development [14]. The initial policy aimed to develop settlements for villagers, mainly by increasing the density of dwellings for the stored land to be reclaimed or developed commercially.

Prevailing values and norms in the social and cultural context of a region or country influence the land management systems applied. Participation from all parties affected by changes in land tenure systems, institutions and local knowledge is mandatory for effective management. Greater participation should involve decentralization and the application of subsidies principle. This process, however, encounters challenges in meeting the principles of customary land during rapid change. Coherent and transparent land policy is needed to solve the complex problem of land tenure, based on guidelines and fundamental principles. It should follow clear objectives at the national, regional and group levels. A coherent set of policy instruments needs to be designed based on these objectives. The three pillars of the land policy include

1. Efficiency and promotion of economic development;

2. Social justice;

3. Environmental protection and sustainable land use. [18].

In the urban sector, this change is apparent in the "Cities without Slums" program. The Cities Alliance consisting of the World Bank, the UN-Habitat, and several bilateral development agencies, coordinates the program (see, e.g., [19] for a slum upgrading case in Nanga Bulik, Central Kalimantan). In rural areas, the 2003 Policy Research Report marked a significant change in recognizing the economic efficiency of the mode of indirect use and legitimacy and the effectiveness of traditional (adat) regulations. To improve the security of ownership, professional organizations, like the International Surveyor Federation (IFS), are involved in a detailed analysis of the instruments and reform of the legal framework [20].

In many cases, aid agencies and bilateral cooperation unevenly apply two approaches, namely, the focus on the social objectives of land policy and the legal frameworks for a free market, that would depend on the countries' characteristics. For instance, agents from Scandinavian countries tend to focus on the social objectives of urban land policies, including universal access to land, services and infrastructure, and environmental and social integration. In contrast, American agencies, such as the United States Agency for International Development (USAID), prefer legal framework reform to enable markets to develop freely and integrate the informal sector into the formal market. Meanwhile, the German, British, and French agencies stand between these two approaches, similar to the European Union. The Land Cooperative in France, for example, has been focusing on bilateral interventions that require joint donor action. It has recently begun working in small ways with civil society organizations to intervene on land issues [20]. 
Meanwhile, Chaddad and Cook [13] suggest six new cooperative models as follows:

\section{Proportional Investment Cooperative}

This type is for cooperatives that adopt an authorized capital plan, which is a comprehensive justice management technique and includes the acquisition and exchange of equitable capital from member users. The first step when introducing an authorized capital plan is to determine cooperative capital requirements based on future investment opportunities and the willingness of members to supply risk capital. Proportional usage is then determined by measuring the average use of each cooperative member during the base period and calculating the minimum equity capital requirements of the members based on relative patronage. In case the plan starts in an "ongoing" cooperative when it has calculated the minimum capital contribution per member, some members might be surplus or less. Therefore, the next step is to design a plan to increase the equity investment of overinvested members. Alternatively, the cooperative can allow members investing less but share from those investing too much. Adoption in the authorized capital plan is thus not complicated in dealing with new cooperative cases.

\section{Member-Investor Cooperative}

In this model, ownership rights are restricted to customers, cannot be transferred and are redeemed. However, the cooperative distributes net income in proportion to the ownership of members' shares rather than patronage. To achieve this, it distributes cash dividends proportionally to member shares or creates policies that allow appreciation of residual claims. The problem of distributing bonuses and valuing stock values is a mechanism often used to value residual claims. When residual claims are large enough, members have more incentives to invest and maintain equity in the cooperative. It is because they are paid explicitly for their investment. The member-investor model is implementable through participation and capital units, as well as preference shares that can be redeemed.

\section{New Generation Cooperative}

The new generation cooperative model is also a change from the traditional cooperative structure that facilitates restrictions on the transfer of residual claims. The reason for the transfer of shares is to provide liquidity and capital appreciation through secondary market valuations. The new generation cooperative model introduces ownership rights in the form of shipping rights traded between clear member protection groups. Ownership rights are limited to customers, membership is closed, members are required to invest in advance in shipping rights based on patronage, and marketing agreements control supply. Therefore, these models relax some restrictions on traditional cooperative residual claims but maintain the principle of user ownership.

\section{Cooperative with Entities Seeking Capital}

This model reduces the restrictions, specifically ownership rights limited to protective members. Cooperatives, however, would not convert to investor-oriented firms (IOF) because a separate legal entity, such as a strategic alliance, a trusted company, or a publicly owned subsidiary, can obtain outside equity capital.

\section{Investor-Share Cooperative}

In this model, a cooperative obtains non-member equity capital without converting to IOF. Unlike the previous model, stock investment cooperatives issue fair share classes separately. This method supplements the traditional cooperative ownership rights held by protective members. Investor shares can combine different ownership rights in terms of returns, risks, controls, redeemable, and transferability. The shares include preferred shares, ordinary shares without voting rights, and certificates of participation. 


\section{Conversion to an Investor-Oriented Company}

Conversion, commonly known as "demutualization", refers to changes in the ownership structure of an organization owned and controlled by users from cooperatives (or reciprocity) to non-profit and proprietary organizations. Due to demutualization, residual claims and control rights are transferable among the company's stakeholders. However, this has implications for the company's behavior and performance. In particular, cooperative membership rights are changed to common share ownership rights that would be less restrictable. Demutualization is usually followed by public listing, which allows the converting company to gain additional risk capital from investors.

Therefore, a land cooperative is an institution that can have an essential role in land management, both in rural and urban areas. It is bound by law and security in transactions and guarantees to landowners and other parties involved. Establishing land cooperatives would thus be essential for the implementation of spatial plans to be successful, especially in Indonesia.

\section{Toward an Indonesian Model}

In Indonesia, the implementation of urban spatial plans, especially the RDTRK, also often faces a kind of land shortage for public use. Although land consolidation can help, rarely has the concept been applicable. This research stands out because it examines the application of land cooperatives at the local level in assuring successful land consolidation while the establishment of the National Land Bank has been in postponement. The land-cooperative establishment can assist local governments to collect land ownership data and bridge the interests of the community, the public and the private sectors in implementing spatial plans (see Figure 2). In more details, the role of land cooperatives includes:

1. Serving-It is from the people and for the people. The capital and members of land cooperatives are from the people, and the benefits are also for the people.

2. Ensuring-Land cooperatives can help the members to ensure their land tenure.

3. Preparing land at affordable prices for development purposes. It is both from private parties as well as communities, in line with the RDTRK.

4. Controlling-Land cooperatives can control land prices to encourage the implementation of the RDTRK.

5. Distributing-The benefit distribution to the cooperative members can be more equitable compared to the no cooperative situation where they are individual landowners only. The land is an essential aspect of the production function in equity-based development, the market mechanism of which usually makes small actors worse-off [21,22].

6. Providing-Land cooperatives can donate land for urban development purposes. In a slum upgrading study in Nanga Bulik small town, Purwanto et al. [19] have found out that community participation has gone beyond expectation to the extent that some members were willing to donate their land for public use to help upgrade their slum settlement as planned. The factor behind it is that those people feel they own the plan as they involve inherently in the planning process as well as the implementation. Land cooperatives can encourage this feeling to scale-up participatory planning practices.

Figure 2 shows how essential the land cooperative would be in ensuring successful implementation of RDTRK. In Indonesia, where cooperatives have become a culture for a long time and can help middle-to-low-income people improve their livelihood, establishing the land cooperative should be able to help the RDTRK implementation. As already highlighted in role number one above, members of land cooperatives are those whose lots would need an alteration in terms of land use conversion or other forms due to the RDTRK implementation. Therefore, when they become members of land cooperatives, which involve significantly in spatial planning as well as implementation, all the expected roles of cooperatives would be there. 




Figure 2. Role of the land cooperative (authors' analysis, 2020).

Additionally, it is worth noting that many people in Indonesia, especially those remote from Jakarta, are still not familiar enough with spatial planning. This is despite the fact that spatial planning practices have been there since the 1960s when the Regional and City Planning Department of the Institute of Technology at Bandung (ITB) started graduating planners. The educational level of Indonesian people is, on average, significantly lower than those of developed countries. Therefore, the land cooperative can also help people to be familiar with spatial planning through the learning by doing of its members in their participation in the planning and implementation process.

Figure 2 also depicts an explanatory scheme of an essential function of the land cooperative, i.e., to bridge landowners and the government to reach agreement on land use planning and implementation. The relationship between the land cooperative and the government aligns the existing situation of land with the spatial plan. It is because the land cooperative participates appropriately in planning and the implementation. Similarly, the relationship between the land cooperative and the community involves collecting data about land use and providing security guarantees for the registered land.

Meanwhile, Figure 3 shows the superimpose framework explaining why the significant discrepancy between the RDTRK and its implementation is often existence in Indonesia (studies like [23,24], for example, although with a different focus, have found out about this issue). Typically, this framework is useful for land use planning, such as the zoning arrangement of a region.

In Figure 3, a particular region can be interpreted in different forms, even regarding its existing situation. As seen in the figure, the existing situation according to the satellite image (layer one from below) may say nothing about land ownerships (layer 2). Similarly, the land ownership map as understood by the people may be different with that of the official version (layer 3) used by the urban planner, especially for the case of Sungai Selan that is in its initial, but rapid, stage of urbanization. Therefore, an appropriate planning process should involve dialogue and high level of participation of the people to yield in a highly implementable spatial plan. In the case of Sungai Selan urban area, the RDTRK of which has been ready for implementation whilst the planning process might not be participatory enough, as in many other cases in Indonesia [19,21,25], establishing land cooperatives would be able to help the stakeholders more prepared in RDTRK implementation. Therefore, assessing the readiness of the RDTRK stakeholders for the establishment of land cooperatives is, perhaps, among the first things to do. 


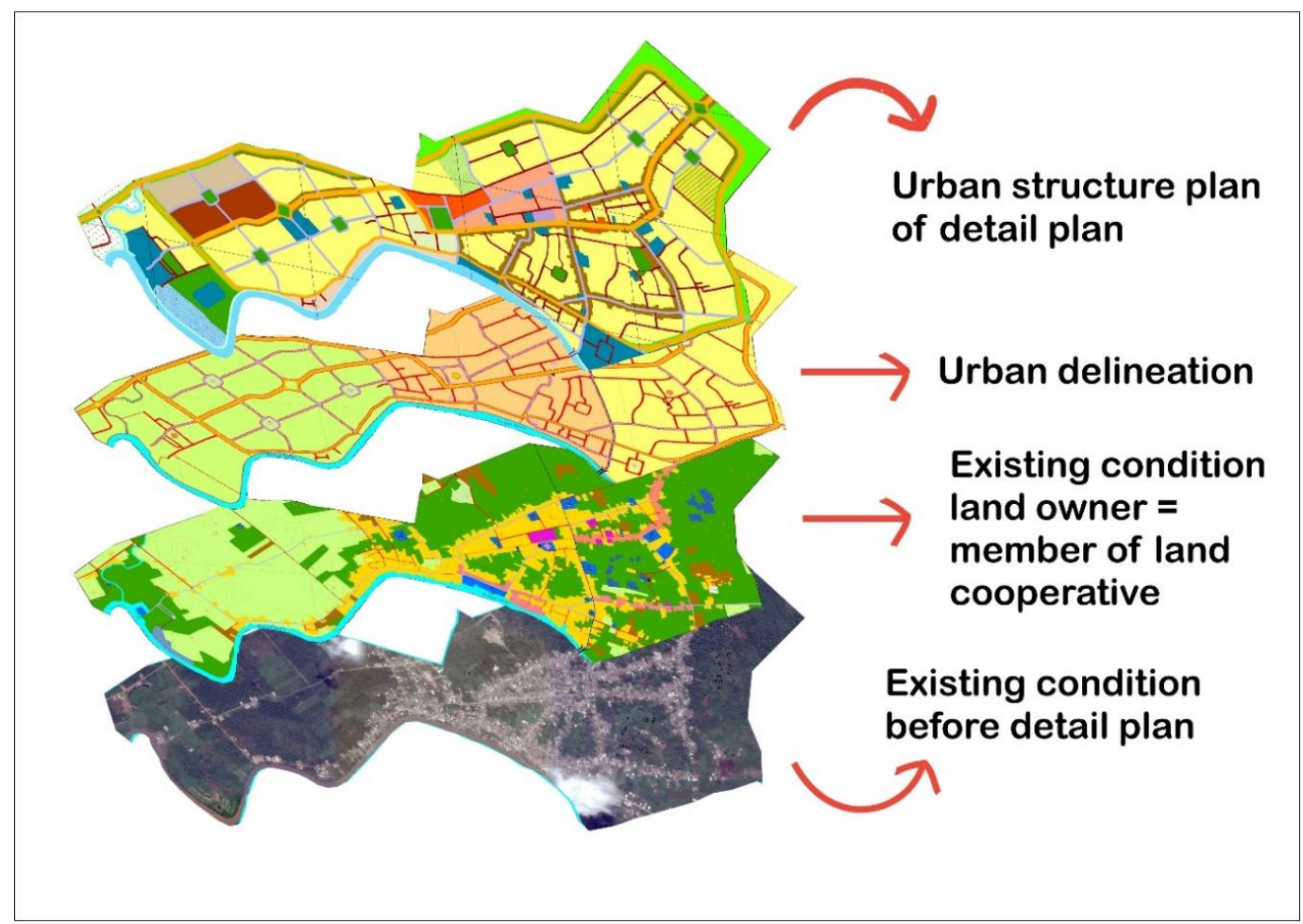

Figure 3. Superimpose framework: from existing to implemented plan (authors' analysis, 2020).

\section{Materials and Methods}

According to the 2017 data from the Central Statistical Bureau, Central Bangka (Bangka Tengah) Regency, located in Bangka Island, has an area of 2279.11 square Km. It comprises six districts (kecamatan): Koba, Pangkalan Baru, Sungai Selan, Simpang Katis, Namang, and Lubuk Besar. The regency is surrounded by beaches and small islands, such as Ketawai, Semujur, Bebuar, Panjang, Begadung, Pelepas, and Nangka. Central Bangka location is precisely at $105^{\circ} 45^{\prime}$ to $106^{\circ} 50^{\prime}$ East Longitude and $2^{\circ} 10^{\prime}$ to $2^{\circ} 50^{\prime}$ South Latitude. It has the following territorial borders:

West Side: Bangka Strait;

East Side: Karimata Strait;

North Side: Bangka Regency and Pangkal Pinang City;

South Side: South Bangka Regency.

The farthest points from the capital of Central Bangka Regency are Koba and Muntok in West Bangka and Sungailiat in Bangka. The closest is the Provincial Capital, Pangkalpinang, $60.42 \mathrm{Km}$ away. The area was sub-divided due to the increasing number of government affairs at the district and village (kelurahan/urban or desa/rural) levels, making regional sub-division a necessity for public services to run optimally.

There were two additional districts in 2006, i.e., Namang that joined from Pangkalan Baru Regency, and Lubuk Besar from Koba Regency. These sub-divisions lead to an increased government status at the village level. For instance, Desa Arung Dalam became Kelurahan Arung Dalam while Desa Sungai Selan transformed into Kelurahan Sungai Selan, raising the number of villages to 50 including seven urban villages. In 2012, the other six villages emerged, bringing the total number to 56 . This research focuses on Sungai Selan urban area, as shown in Figure 4. 


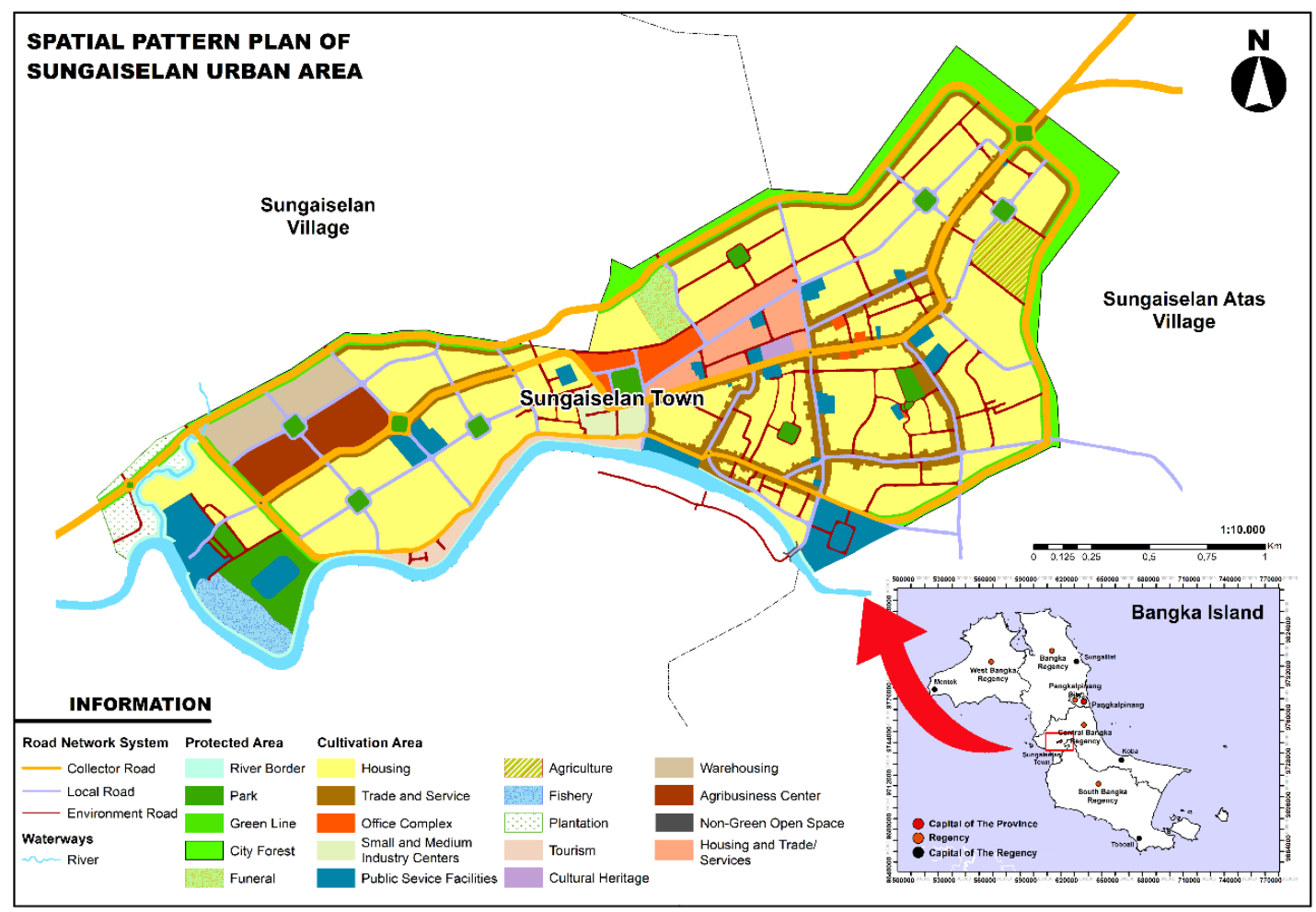

Figure 4. Spatial plan of Sungai Selan urban area (detailed spatial plan of Sungai Selan urban area, 2018).

The selection of Sungai Selan as the case study was for several reasons, including the cooperation between the Central Bangka Regency Government and Diponegoro University in constructing Urban Spatial Plan of Central Bangka Regency. Second, the urban areas of Central Bangka can be considered transition areas converted primarily from oil palm plantations. Third, many pieces of land in the location are already owned by the members of savings and loan cooperatives of palm oil, fisheries and small industries. Therefore, Sungai Selan urban area, which needs collaboration between the local government and landowners for ensuring sustainable urban development, is a suitable case for this study.

This research started at quite the same time as the Covid-19 outbreak, which required the field survey procedure to be adjusted accordingly. Importantly, this study examines the implementation of a Detailed Urban Spatial Plan through the establishment of a local institution as a forum for land management before and after land consolidation, that is, the land cooperative. This study ensures state of the art achieved in understanding the stakeholder readiness in Central Bangka Regency in the implementation of RDTRK through the establishment of the land cooperative. At the moment, many city spatial plans are available to support the local zoning regulations. However, city managers still experience difficulties in the implementation, mainly due to land issues owned by many parties, including communities, investors and land speculators with problems arising during land acquisition. In this regard, studies on land cooperatives are hardly there despite the need.

The study has utilised the method of Analytic Hierarchical Process (AHP) due to the Covid-19 pandemic, which has limited the use of methods that need intensive direct contacts such as observation and interviews. The study has focused on 13 respondents, each of which has an essential role in the implementation of RDTRK, including the establishment of the land cooperative, which makes them appropriate and valid as AHP respondents. They are from the government, the existing cooperatives, and the communities represented by an NGO, as follows:

1. A member of Central Bangka People Representative Council (DPRD) from Sungai Selan electoral district; 
2. An official of the Central Bangka Development Planning and Research Board (Bappelitbangda);

3. An official of Central Bangka Agency for Cooperatives and Micro, Small and Medium Enterprises;

4. An official of Central Bangka Agency for Public Works and Spatial Management;

5. An official of Central Bangka Agency for People Housing and Settlements;

6. An official of Central Bangka Agency for Investment and Integrated One Door Services;

7. An official of Central Bangka Agency for Agriculture;

8. Head of Sungaiselan District;

9. Head of Sungaiselan Village;

10. A senior member of Berkat Yakin Cooperative (representing landowners);

11. A senior member of Tunas Baru Cooperative (representing landowners);

12. A senior member of Harapan Bersama Fishers Cooperative (representing landowners);

13. A senior member of Sungai Selan NGO.

In the initial stage, the researchers conducted an online discussion with the respondents, investigating mainly their view on Sungai Selan people's perceptions about the implementation of RDTRK and the possibility to establish land cooperatives. The respondents, in general, have the view that Sungai Selan people would encourage the implementation of RDTRK and land cooperatives can help to solve problems that may arise like land shortage for public use and the people's land alterations.

Using the AHP method, steps to complete this research involved:

1. Formulating research objectives based on the problem raised;

2. Determine the criteria related to the objectives;

3. Determine the sub-criteria;

4. Develop a priority hierarchy;

5. Arrange pairwise comparison matrices;

6. Weighting criteria;

7. Weighting sub-criteria;

8. Determine the consistency ratio;

9. Make conclusions.

For this reason, it is necessary to design and fill a pairwise comparison matrix [26]. It requires numbers to be set that illustrate the priority of elements on a scale of 1 to 9 , accompanied by an explanation, as seen in Table 1. The hierarchy of pairs arranged and comparison matrices can then be analysed to determine alternatives using several calculation steps, starting from making a paired comparison matrix to calculating the eigenvector value. The final step is to compute the consistency ratio to determine the inconsistencies of the data obtained. This study examined the results of the weighting of 13 respondents. Analytical calculations involved calculating the results on each respondent and then averaging them using several levels. 
Table 1. Analytic hierarchical process (AHP) Priority Scale.

\begin{tabular}{cll}
\hline $\mathbf{1}$ Intensity of Interest & \multicolumn{1}{c}{ Definition } & \multicolumn{1}{c}{ Explanation } \\
\hline 3 & $\begin{array}{l}\text { Both elements or criteria are } \\
\text { equally important. }\end{array}$ & The two have the same effect on purpose. \\
& $\begin{array}{l}\text { One element is slightly more } \\
\text { important than the other element. }\end{array}$ & $\begin{array}{l}\text { Experience and judgment slightly support } \\
\text { one element over another. }\end{array}$ \\
\hline $\mathbf{5}$ & $\begin{array}{l}\text { One element is more important } \\
\text { than the other element. }\end{array}$ & $\begin{array}{l}\text { Experience and judgment are very strong in } \\
\text { supporting one element compared to the } \\
\text { other element. }\end{array}$ \\
\hline $\mathbf{9}$ & $\begin{array}{l}\text { One element is far more critical } \\
\text { than the other element. }\end{array}$ & $\begin{array}{l}\text { One strong and supporting element is seen } \\
\text { in practice. }\end{array}$ \\
\hline $\mathbf{2 , 4 , 6 , 8}$ & $\begin{array}{l}\text { One element is more important } \\
\text { than the other elements. }\end{array}$ & $\begin{array}{l}\text { Evidence which supporting one element } \\
\text { against another has the highest level of } \\
\text { affirmation that might be corroborating. }\end{array}$ \\
\hline The Opposite & $\begin{array}{l}\text { The values between the two } \\
\text { considerations are close together. }\end{array}$ & $\begin{array}{l}\text { This value is given if there are two } \\
\text { compromises between the two choices. }\end{array}$ \\
\hline
\end{tabular}

Source: [26].

Following is the elaboration of the steps in performing AHP calculations, according to [26]:

\section{A. Determine the Election Hierarchy}

The hierarchy consists of three levels, including goal or objective, criteria, and sub-criteria. However, only two levels of hierarchy are used in this study: criteria and sub-criteria. This is because the AHP analysis technique determines the priority of each criterion and sub-criteria in the tree hierarchy levels, as shown in Figure 5 and not an alternative. The criteria and sub-criteria selected are the results of a previous literature review adjusted to the conditions of the study area, Sungai Selan. Table 2 shows the criteria and sub-criteria used in the AHP analysis and the related literature reviewed. Each criterion has different sub-criteria which does not affect the score of other criteria. The priority order is related to the selection of the most critical sub-criteria from the existing ones.

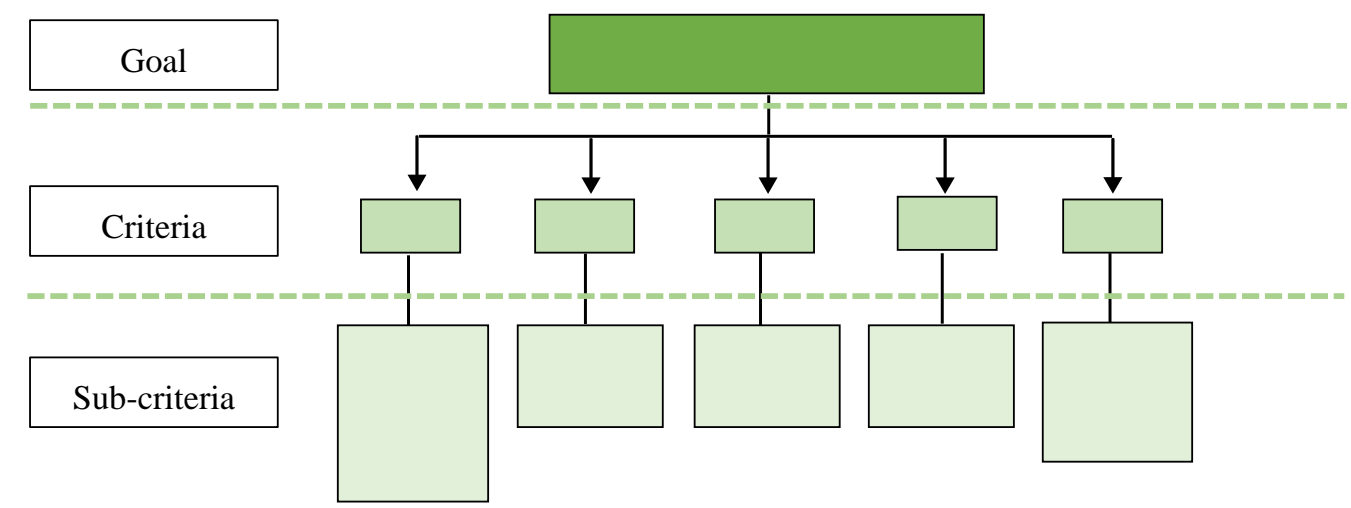

Figure 5. AHP Hierarchy Levels in This Research. Source: authors' analysis, 2020. 
Table 2. Research Criteria and Sub Criteria.

\begin{tabular}{|c|c|}
\hline Criteria & Sub Criteria \\
\hline Controlled Land Prices & $\begin{array}{l}\text { - Land prices are the same as land market prices (real prices) [27]; } \\
\text { - Land prices are affected by the level of demand for land [28,29]; } \\
\text { - Land prices are based on existing location conditions } \\
\text { (including accessibility and infrastructure) [30]; } \\
\text { - Land prices are based on the social conditions of the } \\
\text { community [2]; } \\
\text { - Land prices are based on the economic conditions of the } \\
\text { community [2]. }\end{array}$ \\
\hline Proportional Distribution of Land Area & $\begin{array}{l}\text { Governments and communities alike are willing to make land } \\
\text { donations for development [31]; } \\
\text { There are arrangements for the use, control and ownership of } \\
\text { land [32]. }\end{array}$ \\
\hline Mutual Agreement & $\begin{array}{l}\text { - } \quad \text { Active community participation [33]; } \\
\text { - } 85 \% \text { participant agreement for Land Donations for } \\
\text { Development [31]; } \\
\text { - } \quad \text { Accelerating land administration activities and a more accurate } \\
\text { and fair land taxation system [34,35]; } \\
\text { - } \quad \text { Agreement on land pricing [36]. }\end{array}$ \\
\hline A Mutually Beneficial Agreement & $\begin{array}{ll}\text { - } & \text { Efficient land use planning [33]; } \\
\text { - } & \text { Structuring the use and control of land [35]; } \\
\text { - } & \text { Legal certainty for landowners [37]. }\end{array}$ \\
\hline The Benefits Obtained are Better & $\begin{array}{l}\text { - } \quad \text { Improvement of environmental quality [38]; } \\
\text { - } \quad \text { Increase in land value [39]; } \\
\text { - } \quad \text { Increased land use potential }[33,40]\end{array}$ \\
\hline
\end{tabular}

B. Calculating Vector of Eigenvalues

Before the calculations, a pairwise comparison matrix of element weights is made, where element A with factor $i$ is compared to $A$ with factor $j$ to obtain the formula:

$$
a_{i j}=A_{i} / A_{j} \text {, where } \mathrm{i} \text { and } \mathrm{j}=1,2,3 \ldots \mathrm{n}
$$

The results of pairwise comparisons between elements $A$ above are then expressed in vectors $\mathrm{w}$ including $\mathrm{W} 1, \mathrm{~W} 2, \mathrm{~W} 3, \ldots \mathrm{Wn}$ for the intensity values of the elements expressed in $a_{i j}$ to show the importance of factors $i$ to $j$. The importance of the $j$ to $k$ factor can be stated in $a_{j k}$. For the results to be consistent, the ij must be the same as $a_{j k}$ can be calculated using the formula:

$$
a_{j}=\sum_{i=1}^{n} a i j
$$

The Eigenvector $(\mathrm{Wi})$ value in each row can be calculated using the formula:

$$
W i=n \sqrt{a i 1 \times a i 2 \times a i 3 \ldots \times a i n}
$$

From the results of the $W i$ calculation, the normalized Eigenvector $(X i)$ value in each row is determined with the formula:

$$
X_{i}=W_{i} / \sum W_{i}
$$

The most considerable eigenvector value can be found with maximum lambda using the formula:

$$
\lambda \max =\sum a_{i j} \cdot X_{j}
$$


C. Calculating Consistency Value

It is to determine the level of consistency of the results of the values' weighting by the respondents. In case the value is smaller and closer to 0.1 , the data are declared more consistent. The formula to calculate the consistency is:

$$
C I=(\lambda \max -n) /(n-1)
$$

where:

$\mathrm{CI}=$ Consistency Index

$\lambda \max =$ Maximum Vector Eigenvalue (Maximum Lambda)

$\mathrm{n}=$ matrix size

After the consistency index is obtained, the consistency ratio is determined with the formula:

$$
C R=C I / R I
$$

where:

$\mathrm{CR}=$ Consistency Ratio

$\mathrm{CI}=$ Consistency Index

$\mathrm{RI}=$ Random Index

In the Random Index matrix in Table 3 [26], at least 15 random indices have been determined per order matrix (n).

Table 3. Random Index Matrix.

\begin{tabular}{cccccccccccccccc}
\hline $\mathbf{n}$ & $\mathbf{1}$ & $\mathbf{2}$ & $\mathbf{3}$ & $\mathbf{4}$ & $\mathbf{5}$ & $\mathbf{6}$ & $\mathbf{7}$ & $\mathbf{8}$ & $\mathbf{9}$ & $\mathbf{1 0}$ & $\mathbf{1 1}$ & $\mathbf{1 2}$ & $\mathbf{1 3}$ & $\mathbf{1 4}$ & $\mathbf{1 5}$ \\
\hline $\mathbf{R} \mathbf{1}$ & 0.00 & 0.00 & 0.58 & 0.90 & 1.12 & 1.24 & 1.32 & 1.41 & 1.45 & 1.49 & 1.51 & 1.48 & 1.56 & 1.57 & 1.59 \\
\hline \multicolumn{1}{c}{ Source: $[26]}$. &
\end{tabular}

\section{Results and Discussion}

The results discussed in this section are based on the analysis of data from the distributed questionnaires. Therefore, the data shown are a summary of all respondents in each of the criteria and sub-criteria determined earlier.

A. Results of Level 1 Criteria Analysis

The results of the level 1 analysis use five criteria as described in Table 2. Table 4 shows the results of the eigenvector, lambda max, and CI vectors.

This level 1 criteria analysis has resulted in the criterion of Mutual Benefits Agreements as the top priority because it has the highest eigenvector score of 0.327 . On the other hand, the profit criterion (Better Benefits) is the least priority with its lowest eigenvector score of 0.113 . It confirms a necessary inference that the most important thing to consider regarding the willingness to form a land cooperative is the mutual benefits agreement. The consistency index in the criteria calculation matrix is 0.007 , which is less than 0.1 , inferring that the results are consistent. 
Table 4. Criteria Calculation Matrix.

\begin{tabular}{|c|c|c|c|c|c|c|c|c|c|}
\hline Criteria & 1 & 2 & 3 & 4 & 5 & Eigen Vector & Priority Vector & Lambda Max & $\mathrm{CI}$ \\
\hline 1 & 0.111 & 0.106 & 0.089 & 0.120 & 0.148 & 0.115 & \multirow{5}{*}{5.033} & \multirow{5}{*}{0.008} & \multirow{5}{*}{0.007} \\
\hline 2 & 0.240 & 0.229 & 0.203 & 0.242 & 0.229 & 0.229 & & & \\
\hline 3 & 0.258 & 0.235 & 0.209 & 0.183 & 0.200 & 0.217 & & & \\
\hline 4 & 0.305 & 0.313 & 0.377 & 0.330 & 0.307 & 0.327 & & & \\
\hline 5 & 0.087 & 0.117 & 0.122 & 0.125 & 0.116 & 0.113 & & & \\
\hline
\end{tabular}

Notes: 1: Controlled Land Prices; 2: Proportional Land Area Distribution; 3: Joint Agreements; 4: Mutual Benefits Agreements; 5: Better Benefits. Source: authors' analysis, 2020.

\section{B. Results of Level 2 Criteria Analysis (Sub-Criteria)}

In level 2 criteria analysis, five calculation matrices have resulted, each of which is for the criteria of Controlled Land Prices, Proportional Land Area Distribution, Joint Agreements, Mutual Benefits Agreements, and Better Benefits.

\section{(1) Sub-Criteria of Controlled Land Prices}

The calculation matrix of sub-criteria for the criterion of Controlled Land Prices has used five sub-criteria to calculate the eigenvector, max lambda, and CI vectors, as seen in Table 5.

Table 5. Calculation Matrix of Controlled Land Prices Sub-Criteria.

\begin{tabular}{|c|c|c|c|c|c|c|c|c|c|}
\hline Sub Criteria & 1 & 2 & 3 & 4 & 5 & Eigen Vector & Priority Vector & Lambda Max & CI \\
\hline 1 & 0.240 & 0.273 & 0.206 & 0.236 & 0.265 & 0.244 & \multirow{5}{*}{5.056} & \multirow{5}{*}{0.014} & \multirow{5}{*}{0.012} \\
\hline 2 & 0.248 & 0.283 & 0.329 & 0.238 & 0.270 & 0.274 & & & \\
\hline 3 & 0.352 & 0.260 & 0.302 & 0.296 & 0.320 & 0.306 & & & \\
\hline 4 & 0.063 & 0.073 & 0.063 & 0.062 & 0.039 & 0.060 & & & \\
\hline 5 & 0.097 & 0.111 & 0.100 & 0.169 & 0.106 & 0.117 & & & \\
\hline
\end{tabular}

Calculation in the Controlled Land Prices sub-criteria comprises

1. Land prices equal to market values (real prices);

2. Land prices influenced by the level of demand;

3. Land prices in line with existing location conditions (including accessibility and infrastructure),

4. Land prices according to social conditions;

5. Land prices based on community economic conditions.

The results show that the sub-criterion number 3 (land prices based on existing location conditions) has the highest eigenvector score of 0.306. Contrastingly, sub-criterion number 4 (land prices based on the existing social conditions of the community) has the lowest eigenvector score of 0.06 . It means that the sub-criterion of current location conditions is the most important and influential factor in determining Controlled Land Prices. Moreover, the consistency index of the calculation matrix is 0.012, which is less than 0.1 , showing that the results are consistent.

\section{(2) Sub-Criteria of Proportional Land Area Distribution}

In this analysis, two sub-criteria have been assessed, i.e., (1) the government and (2) the community, to result in the eigenvector, lambda max, CI vectors, as seen in Table 6. 
Table 6. Calculation Matrix of Proportional Land Area Distribution Sub-Criteria.

\begin{tabular}{|c|c|c|c|c|c|c|}
\hline Sub Criteria & 1 & 2 & Eigen Vector & Priority Vector & Lambda Max & CI \\
\hline 1 & 0.794 & 0.794 & 0.794 & \multirow{2}{*}{2.000} & \multirow{2}{*}{0.000} & \multirow{2}{*}{0.000} \\
\hline 2 & 0.206 & 0.206 & 0.206 & & & \\
\hline
\end{tabular}

Source: authors' analysis, 2020.

The government and the community are equally willing to contribute land for development purposes, although the government should be the one to contribute more. Additionally, there are arrangements for land use, control and ownership. However, the Consistency Index (CI) with a value of 0.000 may show that in the AHP assessment, two criteria may not be enough to be compared.

\section{(3) Sub-Criteria of Joint Agreements}

In this analysis, four sub-criteria have been assessed, i.e., (1) active community participation, (2) an agreement of $85 \%$ of participants for Land Donation for Development (STUP), (3) acceleration of land administration activities and a more accurate land taxation system, and (4) a fair agreement to determine land prices, to result in the eigenvector, lambda max, and CI vector, as seen in Table 7.

Table 7. Calculation Matrix of Joint Agreements Sub-Criteria.

\begin{tabular}{|c|c|c|c|c|c|c|c|c|}
\hline Sub Criteria & 1 & 2 & 3 & 4 & Eigen Vector & Priority Vector & Lambda Max & CI \\
\hline 1 & 0.185 & 0.183 & 0.171 & 0.208 & 0.187 & \multirow{4}{*}{4.015} & \multirow{4}{*}{0.005} & \multirow{4}{*}{0.006} \\
\hline 2 & 0.288 & 0.284 & 0.319 & 0.243 & 0.284 & & & \\
\hline 3 & 0.322 & 0.265 & 0.297 & 0.319 & 0.301 & & & \\
\hline 4 & 0.204 & 0.268 & 0.213 & 0.229 & 0.229 & & & \\
\hline
\end{tabular}

It is the sub-criterion of the acceleration of land administration activities and a more accurate taxation system that has the highest eigenvector score of 0.301 . In contrast, active community participation has the lowest eigenvector score of 0.187 . The results show that the respondents are concerned with the accelerating land administration activities and a more accurate and equitable land tax system in making collective agreements. In the CI column, the value obtained is 0.006 , which is less than 0.1. Therefore, the results are consistent.

\section{(4) Sub-Criteria of Mutual Benefits Agreements}

Calculations in this analysis have involved three sub-criteria, i.e., (1) land-use efficiency, (2) land use and control arrangements, and (3) legal certainty for landowners, to result in the eigenvector, lambda max, CI and CR vectors, as seen in Table 8.

Table 8. Calculation Matrix of Mutual Benefits Agreements Sub-Criteria.

\begin{tabular}{|c|c|c|c|c|c|c|c|}
\hline Sub Criteria & 1 & 2 & 3 & Eigen Vector & Priority Vector & Lambda Max & CI \\
\hline 1 & 0.112 & 0.114 & 0.112 & 0.113 & \multirow{3}{*}{3.000} & \multirow{3}{*}{0.000} & \multirow{3}{*}{0.000} \\
\hline 2 & 0.398 & 0.401 & 0.402 & 0.401 & & & \\
\hline 3 & 0.490 & 0.485 & 0.486 & 0.487 & & & \\
\hline
\end{tabular}

Results show that the legal certainty for landowners is considered a top priority, the most critical aspect in implementing mutually beneficial agreements, with an eigenvector score of 0.487 . Meanwhile, the sub-criterion of land use efficiency has the lowest eigenvector score of 0.113 . 


\section{(5) Sub-Criteria of Better Benefits}

Calculations in this analysis have involved three sub-criteria, i.e., (1) improvement of environmental quality, (2) land value, and (3) land use, to result in the eigenvector, lambda max, CI and CR vectors, as seen in Table 9.

Table 9. Calculation Matrix of Better Benefits Sub-Criteria.

\begin{tabular}{|c|c|c|c|c|c|c|c|}
\hline Sub Criteria & 1 & 2 & 3 & Eigen Vector & Priority Vector & Lambda Max & CI \\
\hline 1 & 0.338 & 0.365 & 0.325 & 0.343 & \multirow{3}{*}{3.003} & \multirow{3}{*}{0.002} & \multirow{3}{*}{0.003} \\
\hline 2 & 0.208 & 0.224 & 0.238 & 0.224 & & & \\
\hline 3 & 0.454 & 0.410 & 0.436 & 0.433 & & & \\
\hline
\end{tabular}

Source: authors' analysis, 2020.

The calculation matrix above shows that the sub-criterion of improvement of land use has the highest eigenvector score of 0.433 . Contrastingly, the lowest score of 0.224 belongs to the improvement of land value. These results show that the improvement of land use is the most critical aspect to gain better benefits for all stakeholders. In the CI calculation, the value that comes out is 0.003 , which is less than 0.1 , showing that the results are consistent.

Criteria calculations of levels 1 and 2 have yielded results that are useful in achieving the objective of this AHP analysis. The analysis has come up with valid eigenvector values of all criteria and sub-criteria, identifying their degrees of influence to the AHP goal. Therefore, it has confirmed the conditions of the stakeholders' readiness in establishing the land cooperative.

\section{Policy Implications}

Results of the AHP analysis suggest five conditions for the establishment of the land cooperative to improve the preparedness for the spatial plan implementation. This subsection discusses the policy implications of those conditions, the order of which follows the results of the stakeholders' priorities in the previous analysis, and therefore, the top priority is the first order.

The first condition is that there should be a mutually beneficial agreement, in which the government ensures legal certainty for landowners so that the government, the community and land buyers could get the benefits. It requires the government to facilitate landowners, who will become members of land cooperatives, to obtain land title certificates guaranteed under the applicable law. Reformulation of the land tenure policy is thus essential.

Second, there should be a proportional distribution of land, prioritizing an agreement between the government and the community to donate land for development purposes, which is essential to make room for public space, where the community can enjoy the benefits as well. Therefore, the government should guarantee that this principle is applicable in the land consolidation program in Sungai Selan, an essential way of which is to keep all stakeholders well informed.

The third is about the land administration and taxation system as the AHP results suggest there should be a mutual agreement between related parties, supported by the improvement of land administration activities and a more accurate, equitable, land taxation system. This agreement can prevent inaccurate data that can be a source of potential conflict, where the administrative acceleration could make landowners and buyers insecure.

The fourth condition is that the land price should be controlled since it will be based on the existing location conditions that also include accessibility and infrastructure. It will need a kind of policy that interferes the market mechanism, which is not easy to apply even in Indonesia that is not an entirely market-driven country.

Fifth, the benefits should be distributed more equitably, supported by improved land use. This way, the land being sold would be more attractive and functional for buyers. Again, the facilitating policy for this purpose will most probably have to interfere with the market mechanism. We believe that the 
best way of interfering the market should be by using market-based instruments such as taxation and incentive systems. A study [41] of a different topic has suggested that the application of market-based instruments in Indonesia would face more obstacles than that in the developed countries. It is despite the prospective situation as far as the bottom-up initiatives are concerned.

\section{Conclusions}

As mentioned in the introduction, due to the Covid-19 pandemic, we have changed the approach and methods for this research to quantitative ones to minimize direct person to person contacts. Therefore, this research has the main limitation that is inescapable. Studies concerning the preparedness of any organization to apply new concepts have usually used qualitative, or mix, approach (see, e.g., [42]). However, it is worth noting that all these results of AHP analysis are still useful to get the experts' estimate on the preparedness to establish the land cooperative.

This study concludes that, according to the experts' view, stakeholders in Central Bangka Regency are ready, with certain conditions as mentioned in the policy implications subsection. However, it is worth noting that in addition to individual policy related to each of the five conditions as discussed earlier, at least two general policies could also apply. The first is a kind of social policy to facilitate the smooth transition of the Sungai Selan people from rural culture to urban culture. The facilitation is essential, considering that there are many aspects of rural culture that must be sustainable, such as the culture of community cooperation (gotong-royong) and being willing to sacrifice for the public interest. Such this facilitation has somehow worked quite well in Nanga Bulik urban area of Central Kalimantan [19].

The second is concerning another, not less critical, transition, that is, to the information technology-literate society. As come up from the policy implications subsection that to be successful in applying land consolidation needs well-informed stakeholders, including the community. The local government of Central Bangka can initiate facilitation by making the spatial planning products available to the public, for example, by posting them on local government websites. It would be much better if the local government could improve the facilitation soon, for instance, by letting the people involved in the web-based spatial planning and implementation process. Not only can this way improve people participation, but it applies the principle of transparency in good governance as well.

Author Contributions: R.H. led the research, developed the conceptual framework, the project design, and wrote the article. I.B. contributed in the AHP analysis, and assisted in the article revisions. N.Y. contributed in the project design, and assisted in the article revisions. I.S. contributed in secondary data and regulation aspects during the project. A.S. contributed in the analysis of planning practices and theory relationships, and assisted in the article revisions and writing. B.N. assisted in the AHP analysis and creation of maps and figures. N.R.P. assisted in the AHP analysis and creation of maps and figures. All authors have read and agreed to the published version of the manuscript.

Funding: This research received no external funding; however, Diponegoro University and the Local Government of Central Bangka Regency gave in-kind facilitations during the research.

Acknowledgments: The authors express their gratitude to the Diponegoro University and Central Bangka Regency for facilitating this study. The authors are also grateful to all helps for this research, especially the Department of Urban and Regional Planning and the Institute of Research and Community Services of Diponegoro University. Finally, we express our deep condolences for the recent passing away of one of the authors, Mr Ibnu Saleh, the Regent of Central Bangka, in the midst of combating Covid-19 pandemic. He was a real hero for his region and people. May he rest in peace.

Conflicts of Interest: The authors declare no conflict of interest.

\section{References}

1. Yanbo, Q.; Guang-hui, J.; Zitong, L.; Yaya, T.; Shuwen, W. Understanding rural land use transition and regional consolidation implications in China. Land Use Policy 2019, 82, 742-753. [CrossRef]

2. Tione, S.E.; Holden, S.T. Urban proximity, demand for land and land shadow prices in Malawi. Land Use Policy 2020, 94. [CrossRef] 
3. Seto, K.C.; Kaufmann, R.K. Modeling the drivers of urban land use change in the Pearl River Delta, China: Integrating remote sensing with socioeconomic data. Land Econ. 2003, 79, 106-121. [CrossRef]

4. Du, J.; Thill, J.C.; Peiser, R.B.; Feng, C. Urban land market and land-use changes in post-reform China: A case study of Beijing. Landsc. Urban Plan. 2014, 124, 118-128. [CrossRef]

5. Qin, Y.; Zhu, H.; Zhu, R. Changes in the distribution of land prices in urban China during 2007-2012. Reg. Sci. Urban Econ. 2016, 57, 77-90. [CrossRef]

6. Yuan, F.; Wei, Y.D.; Xiao, W. Land marketization, fiscal decentralization, and the dynamics of urban land prices in transitional China. Land Use Policy 2019, 89. [CrossRef]

7. Manning, C.A. The determinants of intercity home building site price differences. Land Econ. 1988, 64, 1-14. [CrossRef]

8. Alemu, M.M. Sustainable land management. J. Environ. Prot. 2016, 7. [CrossRef]

9. Ziadat, F.; Bunning, S.; De Pauw, E. Land resource planning for sustainable land management: Current and emerging needs in land resource planning for food security, sustainable livelihoods, integrated landscape management and restoration. In FAO Land and Water Division Working Paper 2017; Food and Agriculture Organization of the United Nations (FAO): Rome, Italy, 2017.

10. Demetriou, D.; See, L.; Stillwell, J. A parcel shape index for use in land consolidation planning. Transit. GIS 2013, 17, 861-882. [CrossRef]

11. Munnangi, A.K.; Lohani, B.; Misrab, S.C. A review of land consolidation in the state of Uttar Pradesh, India: Qualitative approach. Land Use Policy 2020, 90. [CrossRef]

12. Alexander, F.S. Land Bank Authorities: A Guide for the Creation and Operation of Land Banks; Local Initiatives Support Corporation: Boston, MA, USA, 2005.

13. Chaddad, F.R.; Cook, M.L. Understanding new cooperative models: An ownership-control rights typology. Appl. Econ. Perspect. Policy 2004, 26, 348-360. [CrossRef]

14. Dang, S.; Yuan, D.; Kong, W. Land cooperatives as an approach of suburban space construction: Under the reform of Chinese land transfer market. Front. Archit. Res. 2016, 5, 425-432. [CrossRef]

15. Conybeare, J.A.C. Bureaucracy, monopoly, and competition: A critical analysis of the budget- maximizing model of bureaucracy. Am. J. Polit. Sci. 1984, 28, 479-502. [CrossRef]

16. Gerhardus, B.; Weller-Molongua, C. Land in German Development Cooperation: Guiding Principles, Challenges and Prospects for the Future; Deutsche Gesellschaft für Internationale Zusammenarbeit: Bonn, Germany, 2015.

17. Burjorjee, P.; Nelis, Y.; Roth, B. Land Cooperatives as a Model for Sustainable Agriculture: A Case Study in Germany. Master's Thesis, Blekinge Institute of Technology, Karlskrona, Sweden, 2017.

18. Zimmermann, W.; Löffler, U.; Kirk, M. Land Tenure in Development Cooperation Guiding Principles; Deutsche Gesellschaft für Technische Zusammenarbeit (GTZ) GmbH: Eschborn, Germany, 1998.

19. Purwanto, E.; Sugiri, A.; Novian, R. Determined slum upgrading: A challenge to participatory planning in Nanga Bulik, Central Kalimantan, Indonesia. Sustainability 2017, 9, 1261. [CrossRef]

20. Delville, P.L.; Durand-Lasserve, A. Land Governance and Security of Tenure in Developing Countries; Comité technique Foncier et développement (CTFD): Paris, France, 2009.

21. Sugiri, A.; Nuraini, N. Towards equity-based regional development: Addressing spatial inequality in the Blitar Region. Int. J. Civ. Polit. Commun. Stud. 2013, 10, 91-109. [CrossRef]

22. Sugiri, A.; Purba, Y. Kesenjangan spasial dan kegagalan keadilan pada fungsi produksi di wilayah Blitar. Plano Madani J. Perenc. Wil. Kota. 2017, 6, 46-59. [CrossRef]

23. Buchori, I.; Sugiri, A. An empirical examination of sustainable metropolitan development in Semarang City, Indonesia. Aust. Plan. 2016, 53, 163-177. [CrossRef]

24. Buchori, I.; Sugiri, A.; Hadi, S.P.; Wadley, D.; Liu, Y. Developing a geographic information system-based assessment model for sustainable metropolitan development: The case of the Semarang Metropolitan Region, Indonesia. Am. J. Environ. Sci. 2015, 11, 62-75. [CrossRef]

25. Sugiri, A.; Buchori, I.; Ma'rif, S. Towards participatory spatial policy: Facilitating rural non-farm activities in Susukan suburb of Semarang metropolitan region. Int. J. Civ. Polit. Commun. Stud. 2015, 13, 1-17. [CrossRef]

26. Saaty, T.L.; Kearns, K.P. Analytical Planning: The Organization of Systems, 1st ed.; Pergamon Press: Oxford, UK, 1985.

27. Evans, A.W. Economics and Land Use Planning: Real Estate Issues; John Wiley \& Sons: New York, NY, USA, 2008.

28. Waddell, P.; Moore, T. Forecasting Demand for Urban Land. In Urban Ecology; Springer: Boston, MA, USA, 2001. [CrossRef] 
29. Gans, J.S. Weak versus strong net neutrality. J. Regul. Econ. 2015, 47, 183-200. [CrossRef]

30. Zhuang, X.; Zhao, S. Effects of land and building usage on population, land price and passengers in station areas: A case study in Fukuoka, Japan. Front. Archit. Res. 2014, 3. [CrossRef]

31. Mulyanti, W. Pengaruh konsolidasi lahan perkotaan terhadap harga tanah di Ringintelu, Kelurahan Kalipancur-Kota Semarang. J. Pembang. Wil. Kota 2015, 11, 63-75. [CrossRef]

32. Surono, A. Penguasaan, Pemilikan, Penggunaan dan Pemanfaatan Tanah ( $p 4 t)$, 1st ed.; Universitas Al-Azhar: Jakarta, Indonesia, 2013.

33. Ariyani, N.M.D.; Parsa, I.W. Konsolidasi Tanah Sebagai Upaya Meningkatkan Efisiensi dan Produktivitas Pemanfaatan Tanah Perkotaan Secara Optimal, Udayana University, Denpasar, Indonesia. Unpublished work. 2019. Available online: https://ojs.unud.ac.id/index.php/Kerthanegara/article/view/50238/29893 (accessed on 25 May 2020).

34. Aditya, T.; Maria-Unger, E.; Bennett, R.; Saers, P.; Lukman Syahid, H.; Erwan, D.; Wits, T.; Widjajanti, N.; Budi Santosa, P.; Atunggal, D.; et al. Participatory Land Administration in Indonesia: Quality and Usability Assessment. Land 2020, 9, 79. [CrossRef]

35. Santoso, U. Hukum Perumahan; Prenada Media Grup: Jakarta, Indonesia, 2014.

36. Afriyandi, T. Kewenangan pemerintah daerah dalam menentukan harga jual dalam transaksi jual beli tanah dan atau bangunan. J. Huk. Volkgeist 2018, 3, 29-43. [CrossRef]

37. Hadisiswati, I. Kepastian hukum dan perlindungan hukum hak atas tanah. Jurnal 2014, 2, 119. Available online: http://ejournal.iain-tulungagung.ac.id/ (accessed on 25 May 2020).

38. Raharjanto, A.D. Pelaksanaan Konsolidasi Tanah Perkotaan Secara Swadaya Dalam Rangka Peningkatan Kualitas Lingkungan Permukiman (Studi Kasus di Desa Nambangan, Kecamatan Selogiri, Kabupaten Wonogiri). Bachelor's Thesis, Universitas Negeri Sebelas Maret, Surakarta, Indonesia, Unpublished work. 2008. Available online: https://digilib.uns.ac.id/dokumen/download/8085/ (accessed on 25 May 2020).

39. Nurlinda, I. Metode konsolidasi tanah untuk pengadaan tanah yang partisipasif dan penataan ruang yang terpadu. J. Huk. 2010, 18. Available online: https://media.neliti.com/ (accessed on 4 June 2020).

40. Ariesta, I.P.A.S. Penataan tanah perkotaan dalam upaya meningkatkan daya guna dan hasil guna penggunaan tanah melalui konsolidasi tanah (land consolidation) di Denpasar Utara-Bali. Master's Thesis, Universitas Diponegoro, Semarang, Indonesia, Unpublished work. 2008. Unpublished work. Available online: http://eprints.undip.ac.id/17682/ (accessed on 4 June 2020).

41. Sugiri, A.; Buchori, I. Towards low emission development: Prospects of applying MBIs in the industrial sector of Central Java, Indonesia. Am. J. Environ. Sci. 2016, 12, 225-236. [CrossRef]

42. Sugiri, A. Preparedness in implementing action plan for reducing GHGs: The case of Central Java. Am. J. Environ. Sci. 2015, 11, 13-27. [CrossRef]

Publisher's Note: MDPI stays neutral with regard to jurisdictional claims in published maps and institutional affiliations.

(C) 2020 by the authors. Licensee MDPI, Basel, Switzerland. This article is an open access article distributed under the terms and conditions of the Creative Commons Attribution (CC BY) license (http://creativecommons.org/licenses/by/4.0/). 